\title{
Transformative agroecology learning in Europe: building consciousness, skills and collective capacity for food sovereignty
}

\author{
Colin R. Anderson $^{1} \cdot$ Chris Maughan $^{1} \cdot$ Michel P. Pimbert $^{1}$
}

Accepted: 19 October 2018 / Published online: 12 November 2018

(c) The Author(s) 2018

\begin{abstract}
Agroecology has been proposed as a key building block for food sovereignty. This article examines the meaning, practices and potentials of 'transformative agroecology learning' as a collective strategy for food system transformation. Our study is based on our qualitative and action research with the European Coordination of Via Campesina to develop the European Agroecology Knowledge Exchange Network (EAKEN). This network is linked to the global network of La Via Campesina and builds on the strong experiences and traditions of popular education in Latin American peasant movements. Rather than focusing on agroecology education as a process of individual learning, we analyse how a transformative agroecology education can be strengthened as a critical repertoire of action used by social movements to advance food sovereignty. Our analysis contributes a new theory of transformative agroecology learning based on four key characteristics or qualities: horizontalism; diálogo de saberes (wisdom dialogues); combining practical and political knowledge; and building social movement networks. While these different elements of transformative agroecology learning were present across EAKEN, they were unevenly developed and, in many cases, not systematized. The framework can help to strategically and reflexively systematize and strengthen a transformative agroecology learning approach as a key building block for food sovereignty.
\end{abstract}

Keywords Agroecology $\cdot$ Pedagogy $\cdot$ Learning $\cdot$ Sustainable agriculture $\cdot$ Food sovereignty $\cdot$ Europe $\cdot$ Popular education

\section{Introduction}

Food sovereignty has emerged as the most important global discourse around which social movements are organising to contest and challenge neoliberal development (Wittman 2011). Food sovereignty has been taken up by rural and urban social movements around the world as a radical political project of food system transformation that emphasises the democratisation of agriculture and food, rights of food producers and autonomy from powerful external actors (e.g. agribusiness, political elite). As a transformative project, food sovereignty involves the creative re-visioning and fundamental re-design of whole systems. It requires seeing things differently from business as usual industrial food and farming, doing better things and re-thinking food systems on a participative basis (Pimbert 2008). This involves a questioning of the logics and accounting that underpin the

Colin R. Anderson

colin.anderson@coventry.ac.uk

1 Centre for Agroecology, Water and Resilience, Coventry University, Priory Street, Coventry CV1 5FB, UK dominant modes of agriculture through learning processes that force ruptures in conventional thinking and practice. This deep learning asks 'why' questions about underlying paradigms, norms and values as well as the governance and decision-making processes that frame and legitimize the purpose of knowledge, policies, organizations, technologies and practice.

Agroecology has been developed by social movements as an inseparable component of food sovereignty and a key component of its transformative project. Agroecology provides an alternative set of principles to organize the food systems based on maximizing the positive interrelations between people, farming and nature, and increasing the autonomy of farmers (Nyéléni 2015; Pimbert 2015; Wittman 2011). While work on food sovereignty tends to emphasize contentious political activities such as protest and advocacy, agroecology represents the on the ground articulation of food sovereignty in the practices of food producers as the basis for an alternative food system.

The alignment of agroecology and food sovereignty, however, is not always self-evident, largely because agroecology has become a concept with multiple meanings-there are 
multiple 'agroecologies' (Holt-Giménez and Altieri 2016). While agroecology can be rooted in food sovereignty, it can also be used with a narrow technocratic framing by mainstream institutions and scientists in ways that undermine its radical political potential (Holt-Giménez and Altieri 2016; Nyéléni 2015; Levidow et al. 2014; Pimbert 2018; Levidow 2015). On the other hand, social movements are developing and employing strategies to better link agroecology and food sovereignty. However, there is little known about the specific processes that social movements are using to ensure that agroecology and food sovereignty are mutually reinforcing.

In this paper, our goal is to examine the key principles guiding the emergence and implementation of a transformative agroecological learning approach. Learning and knowledge exchange, which have been endorsed both by social movements (Nyéléni 2015) and mainstream institutions (FAO 2018; AgriCultures 2013), are a key area to support the amplification or the scaling of agroecology. Following Mier y Terán et al. (2018), we see such scaling as inclusive of different actors with vastly different politics and intentions who co-define and shape agroecological knowledge, learning and innovation. In this context, different actors with different politics and intentions are required to define and shape agroecological knowledge, learning and innovation (IAASTD 2009; Levidow et al. 2014; Pimbert 2018). Thus, it is critical to examine and articulate the collective processes of learning being advanced by its practitioners. Negotiated and developed from the grassroots level, we argue that agroecological learning helps to weave the connective tissue between the more abstract politics of food sovereignty and the in situ practice of agroecology.

This article draws from our work with the European Coordination of La Via Campesina (LVC) to establish the European Agroecology Knowledge Exchange Network (EAKEN). Through a qualitative and action research approach, we develop a framework that characterises transformative agroecological learning for food sovereignty. This paper thus contributes to the growing literature on the strategies and challenges of implementing food sovereignty in different contexts (Edelman 2014) and on agroecology as an alternative development paradigm (Pimbert 2015; Levidow et al. 2014; Martínez-Torres and Rosset 2014). The article also fills a geographic gap, focusing on agroecology and agroecology learning in European social movements. Whereas an "agroecological revolution" has ostensibly taken hold in some parts of Latin America (Altieri and Toledo 2011), agroecology is a relatively new concept in Europe and there is a need for critical inquiry into the dynamics, tensions and opportunities at play there.

\section{Agroecology and food sovereignty}

Food sovereignty first appeared as a prominent discourse in the public sphere through La Via Campesina at the 1996 World Food Summit in Rome (Patel 2009). It arose in the context of growing rural crises stemming from political and structural conditions, including the dismantling of infrastructural support, the liberalization of agricultural markets, and the increasing enclosure of food and agricultural policy-making by transnational entities such as the WTO (Desmarais 2007; Martínez-Torres and Rosset 2014; McMichael 2008).

Food sovereignty emphasizes the democratisation of food systems, policy, practice and knowledge, particularly the rights and autonomy of food producers (Nyéléni declaration 2007; Wittman 2011; Pimbert 2008). It also entails a rejection of the politics that have come to underpin the dominant food security discourse, which is viewed as being based on technical fixes rather than addressing the political underpinnings of problems in the food system (Lang 2010). Thus, food sovereignty in many ways arose to contest the dominance of scientists, NGOs, policy makers and corporates as the sole protagonists in the development of food systems.

Despite substantial popularity among social movement groups, food sovereignty has not escaped controversy within academic circles. Criticisms have clustered around a perceived 'lack of specificity' (Edelman 2014; Patel 2009; Aerni 2011), its vulnerability to corporate capture or containment (Alonso-Fradejas et al. 2015), fears regarding its overlap with crude nationalism or 'agrarian populism' (Bernstein 2014), as well as limited applicability outside rural space and the Global South (Aerni 2011). In this context, agroecology has been advanced by some as a counterpoint to food sovereignty's more abstract political objectives, that is, not only as a science and a set of agricultural practices, but also as a repertoire of practices capable of resisting corporate capture and containment (Pimbert 2008; Altieri 2009; Wezel et al. 2009).

Increasingly, social movements have positioned the food sovereignty project as inseparable from agroecology as a paradigm for an alternative food system (La Via Campesina 2013; Nyéléni 2015). Agroecology promotes a functional biodiversity and nutrient cycling and the principle of working with nature (Altieri 2009; Gliessman 2014). It seeks to maximize the autonomy of food providers, emphasising and drawing on farmers' knowledge and local resources, while challenging power structures for social and ecological transformation (Nyéléni 2015; Pimbert 2015; Wezel et al. 2009). Rather than imposing a prescriptive framework, agroecology has been praised for its articulation of a set of values and principles flexible 
enough to allow bespoke implementation in specific territorial contexts, reflecting the social, political and biocultural contingencies of place (Nyéléni 2015; Francis et al. 2013; Méndez et al. 2015). This sharply contrasts with top-down attempts to replicate a generalised agroecology which immediately divorces it from the place-based, social and political moorings which define agroecology (González de Molina 2013). Indeed, while mainstream institutions such as the FAO and the French government have taken up agroecology in their policy discourse, they have also been criticised for reframing agroecology in narrow technocratic terms. The de-politicisation and reshaping of the agroecology discourse risks a conformity to the dominant industrial food and farming system (Levidow et al. 2014; Nyéléni 2015; Holt-Giménez and Altieri 2016; Giraldo and Rosset 2018), in ways that have already played out within the contested framings and definitions of sustainable agriculture, organic agriculture and sustainable development (Guthman 2018; Lélé 1991).

In contrast, food sovereignty is based on the theory that transformative change directly depends on learning and 'development' approaches in which agroecological food producers and citizens are the main protagonists. Farmer organisations and social movements are thus developing and arguing for agroecological 'amplification' processes that are controlled from the bottom up through farmer-driven innovation systems, seed networks, and markets (Nyeleni 2015). Rooted in a food sovereignty perspective, food producers and citizens are claiming their right to define agroecological development (Rosset and Altieri 2017). That said, as a complex, place-specific approach, agroecology presents many challenges to those seeking to understand how it can be up-scaled, extended, or amplified across many locations (Warner 2007).

\section{Agroecology, knowledge and learning: social movement building}

Agroecology is knowledge-intensive rather than resourceintensive and thus bolstering knowledge has been claimed as a critical element of any strategy to amplify agroecology. However, formal learning institutions and agricultural extensions generally reflect and institutionalise modernising and elite knowledges that devalue peasant and farmer knowledge (Coolsaet 2016; Meek 2015). Positioned as an alternative paradigm, agroecology as a component of food sovereignty implies an approach to learning that is also transformative in politics and practice.

There is a body of literature on learning that examines processes of learning that allow for personal transformation. Mezirow (1997) defined transformative learning focusing on experiences that have a significant impact on the learner, leading to a paradigm shift that shapes the learner and affects subsequent experiences. While this body of thinking has useful elements in terms of imagining the micro-processes of teaching and learning, it tends to focus on individual learning and change. Whilst individual change is important, agroecology and food sovereignty are being construed as collective political projects that require imagining learning as a strategy of social movement mobilization.

Indeed, social movements advance their own programs of learning and knowledge production that resist the cultural and technical hegemony imposed through agricultural education and other mainstream knowledge institutions (HoltGiménez 2006; McCune and Sánchez 2019; Freire 1972). Food sovereignty calls for the democratisation of knowledge and learning (Pimbert 2018), and a rejection of the "elite control of education, by also carrying out an agrarian reform of knowledge and culture" (MST 2005, 31 in Barbosa 2016). Knowledge that is collectively developed and held in the autonomous spaces of farmer and community networks is vital for achieving sustainable and just food systems. Social movements have been long articulating this claim including in the recent declaration of the International Forum on Agroecology (Nyéléni 2015):

Our learning processes are horizontal and peer-topeer, based on popular education. They take place in our own training centers and territories (farmers teach farmers, fishers teach fishers, etc.), and are also intergenerational, with exchange of knowledge between youth and elders. Agroecology is developed through our own innovation, research, and crop and livestock selection and breeding.

Social movements have rooted much of their learning approaches in a popular education approach (Freire 1972), seeking to raise critical consciousness for transformation, people's empowerment, and the combination of critical theory and political action. Critical pedagogy helps students learn, "to perceive social, political, and economic contradictions, and to take action against the oppressive elements of reality" (Freire 1972). Echoing a long tradition of popular education in Europe (Pelloutier 1901; Gramsci 1971; Ferrer 1996), Scandinavia (Broadbridge et al. 2011), and the Americas (Dewey 1916; Adams and Horton 1975; Freire 1972; McCune and Sánchez 2019), grassroots networks use education as a tool to explore how an individual's personal experiences and learning are linked to larger societal problems and how to transform social and economic injustice in their communities and wider society. Education for critical consciousness usually reflects a deep commitment to radical democracy and human rights (Amsler 2015).

A growing literature, largely from the Latin American context, provides insight into popular education in agrarian movements (Meek 2015; Martínez-Torres and Rosset 
2014; Nyéléni 2007, 2015; Wezel et al. 2009; Warner 2007). In the context of food sovereignty, participation social movements is an educational process where it is important to recognise not only the plurality of voices at the grassroots, but as a way to ensure knowledge production is situated there, rather than transmitted from 'above' (Martínez-Torres and Rosset 2014). Focusing on Latin America, Barbosa (2016) highlights the importance of education in the formation of 'the landless identity' as a basis for raising collective consciousness as the basis for social movement mobilisation. There has been minimal attention to how the lessons learned in the historical and cultural context of Latin American resonate with experience in other regions.

European studies are scarce in the literature on grassroots agroecology learning. One exception is Coolsaet (2016) who examines a participatory plant breeding network to demonstrate how agroecology learning can be used as a path towards cognitive justice. Coolsaet joins other commentators in claiming that agroecology necessitates collective learning processes and co-creation of knowledge. However, the study is based on a single case study and also foregoes the development of a more expansive framework commensurate with the scale of agroecology as a global science, movement, and practice. Meek and Tarlau (2016) offer a framework consisting of critical pedagogy, food justice, food sovereignty, and agroecology. While this approach is helpful in developing the linkages between these approaches, our paper focuses on how learning is unfolding on the ground, in the stragegies and processes of social movement building.

This literature provides strong coverage of the Latin American perspective and offers a compelling case for transformative agroecology learning; what it lacks, however, is a coherent framework, one which would be useful to apply at a frontier of agroecology learning, such as Europe or North America. Moreover, while a valorization of local and peasant knowledge and grassroots processes is common in the literature, shifting the locus of education and development to the grassroots does not automatically equate to processes of social transformation. The strategies and processes of transformative empowerment approaches-such as learning and education-are complex. Whilst there is a general sense that popular agroecological education is an important strategy for social movements, there is a need to critically interrogate the mechanisms and theories of change that link popular education to movement building.

The purpose of this paper is to build on the above literature to develop the key principles to guide the implementation of a transformative agroecological learning approach in the hitherto under-examined European context. Our analysis characterizes the emergent European agroecology learning networks and their basis in a critical and strategic knowledge strategy, one based on grassroots knowledge production for the explicit purpose of system transformation.

\section{Methodology}

In June 2014, the European Coordination of Via Campesina (ECVC) initiated the formation of a network of agroecology learning in Europe as a strategy to amplify agroecological transformation and to advance food sovereignty (ECVC, n.d.). ECVC is a European network made up of 28 national and regional organisations working to change agriculture policies, defend food sovereignty and peasant rights and create solidarity and exchange between members. EAKEN is an articulation of a wider effort coordinated by La Via Campesina to support the development of Agroecology Learning and Agroecology Schools in the major regions of the world. This article is based on the first stage of the development of this European network which focused on mapping out the dynamics, processes and state of agroecology learning amongst grassroots organisations in Europe.

\section{Interviews}

Following an extensive search for participants among ECVC's national 'focal point' contacts, as well as the researchers' own networks, we arranged and conducted 19 semi-structured interviews (Table 1). Specifically, we interviewed leaders from European training initiatives that are directly linked to political movements for food sovereignty and agroecology. These interviews generally lasted between 40 and $90 \mathrm{~min}$, and each participant was asked to describe: (1) the training initiative they are involved in; (2) the key dynamics of agroecology training; (3) the factors supporting or hindering agroecology training; (4) the extent to which government and higher education institutions are involved in agroecology learning; (5) the challenges and opportunities they face in their particular context; and (6) to what extent it would be useful to connect with other agroecology learning initiatives in different parts of Europe.

\section{Analysis and iterative coding process}

Interview recordings were transcribed, analysed, and coded in 'Dedoose' qualitative analysis software. Using an iterative approach, our aim was to build up a set of codes to characterise what our interviewees perceived to be the key themes and concepts at play within agroecological learning, especially based on responses to questions 1-4 (above). Each transcript was initially coded using open coding, focusing on reading for immediate meaning in the transcripts. Researchers then reconvened to compare coding structures and a simplified set of 'master codes' were identified. 
Table 1 List of interviewees

\begin{tabular}{|c|c|c|c|c|}
\hline $\begin{array}{l}\text { Interview } \\
\text { number }\end{array}$ & Organisation & Name & Country & Gender \\
\hline 1 & Agronauten & Peter Volz & Germany & M \\
\hline 2 & Boerengroep & Elske Hageraats & Netherlands & $\mathrm{F}$ \\
\hline 3 & Butterfly development (Pro-Cserehat Association) & Katalin Rethy & Hungary & $\mathrm{F}$ \\
\hline 4 & Collectif en Agroécologie Paysanne & Felix Gauthier & France & M \\
\hline 5 & Eco Ruralis & Ramona Duminicioiu & Romania & $\mathrm{F}$ \\
\hline 6 & EHNE-Bizkaia & Ana Gonzalez & Basque Country & $\mathrm{F}$ \\
\hline 7 & Ileia & Diana Quiroz & Netherlands & $\mathrm{F}$ \\
\hline 8 & $\begin{array}{l}\text { Instituto de Sociología y Estudios Campesinos-ISEC } \\
\text { (Universidad de Córdoba) }\end{array}$ & Mamen Cuellar Padilla & Spain & $\mathrm{F}$ \\
\hline 9 & L'Atelier Paysan & Julien Reynier & France & M \\
\hline 10 & La ligne d'horizon & Sylvia Perez Vitoria & France & $\mathrm{F}$ \\
\hline 11 & Land Base & Dan Powell & England & M \\
\hline 12 & Mouvement Action Paysanne (MAP) & Catherine Tellier & Belgium & $\mathrm{F}$ \\
\hline 13 & Nordbruk & Joel Holmdahl & Sweden & M \\
\hline 14 & Norske bonde-og Smabrukarlag (NBS) & Marielle de Roos & Norway & $\mathrm{F}$ \\
\hline 15 & The Landworker's Alliance & Lucy Otto & England & $\mathrm{F}$ \\
\hline 16 & Toekomstboeren & Jildou Friso & Netherlands & $\mathrm{F}$ \\
\hline 17 & Torth y Tir & Rupert Dunn & Wales & M \\
\hline 18 & URGENCI & Gaelle Bigler & Various & $\mathrm{F}$ \\
\hline 19 & URGENCI & Judith Hitchman & Various & $\mathrm{F}$ \\
\hline
\end{tabular}

At this point, researchers prepared a 'research brief' detailing basic findings structured around these 'master codes', a later version of which can be found on the ECVC website (Anderson et al. 2017a, b). This research brief was taken to the Nyéléni Europe Forum for Food Sovereignty, in Cluj-Napoca, Romania in October 2016 and shared widely, including with those who had already given interviews. Further interviews were conducted at this stage. This began a period of iterative development of our coding structure through participatory workshops, in-person conversations and additional interviews. Over the next 9 months, three further iterations were completed during which we continued to refine our coding structure by identifing redundant aspects as well as those in need of development, before finalising our coding structure. These iterative cycles are detailed in Fig. 1.

\section{Network development}

Our participation and contribution to the development of EAKEN have played a key role in our iterative analysis, offering opportunities for further listening and triangulation, and to reflect on the gradual building up of our analysis. Two participatory workshops at the Nyéléni Forum-involving approximately 150 people, including many of our interviewees-were used to recruit participants for the next meeting, a 3 day workshop in the UK. This workshop focused on debating the purpose and functioning of the emerging EAKEN network, and articulating a statement on Agroecology Knowledge Exchange (ECVC 2017). A further two meetings at strategic movement gatherings were used both as an opportunity to maintain momentum within the network but also as to continue the development of our coding structure into something of use to movement practitioners (Fig. 1). In the following sections we present our findings through this framework, in what we have labelled 'four pillars' of a transformative agroecology learning approach. These four pillars are as follows:

1. Diálogo de saberes (wisdom dialogues)

2. Horizontal learning

3. Combining the practical and the political

4. Building multi-scale social movement networks

\section{Agroecology learning initiatives in Europe: Findings}

The grassroots organisations represented in our interviews were involved in a wide range of education approaches, including internships, apprenticeships, workshops, 


\section{ITERATIVE CYCLES}

1

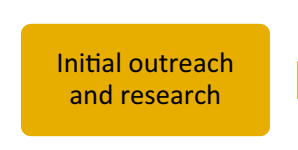

July-October

(2016)
2

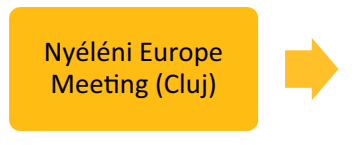

October

(2016)
3

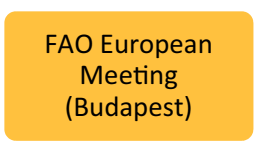

November

(2016)
4

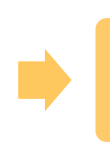

European network meeting (U.K.)

February

(2017)

5

La Via Campesina Meeting in the Basque Country

July

(2017)
- 16 interviews conducted with European agroecology initiatives

- Participants invited to meet up at Nyéléni Europe

- First draft of research brief completed
- Meet in-person with interviewees

- Research brief circulated and initial codes discussed

- 3 further interviews conducted

- 2 participatory workshops to discuss and plan network

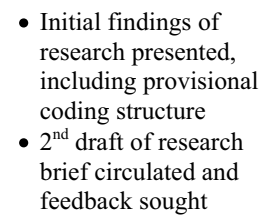

- Initial findings of research presented, including provisional coding structure

- $2^{\text {nd }}$ draft of research brief circulated and feedback sought

- First official meeting of EAKEN based around an 'exchange of experiences'

- Grant writing and project development

- Curriculum and resource development
- Final conversations with interviewees and other agroecology trainers

- Codes finalised

- Article writing begins

\section{RESEARCHERS REFLECT AND ADAPT CODING STRUCTURE}

Fig. 1 Iterative stages of research design

skillshares, international gatherings and also joint programs with universities. All of these agroecological initiatives focused on aspects of practical learning, including appropriate technologies, seed saving, increasing soil fertility, animal rearing, marketing, and agroecological farm design. Thus, 'practical' learning about how to effectively implement on-farm agroecological practices were viewed as important to improve agroecological farming systems, enhance the viability of farm businesses and to maximize farm autonomy from external input suppliers.

However, while the practical was central in agroecology learning, it was also clear from our interviews and workshops that agroecological skills and practices only represent one facet of a transformative agroecological learning approach. In the next section, we turn to the additional strategies and characteristics that build on the practical and form the basis of what we call a Transformative Agroecology Learning. Our analysis focused on drawing out the approaches, characteristics and methodologies that were most important in linking agroecology with the political project of food sovereignty. This analysis gave rise to four pillars of said approach, and in the following sections, we discuss the general principles of each pillar, illustrating them using examples shared in our interviews and in our action research.

\section{Diálogo de saberes (wisdom dialogues)}

Among the representatives of the network that made up our study, a significant emphasis was placed on bringing together actors from different backgrounds. The growing success of rural social movements, and particularly La Via Campesina, has been in part attributed to the ability to foster a diálogo de saberes (translated as 'wisdom dialogues' or roughly the equivalent of dialogue between ways of knowing) amongst different rural peoples. While these situated knowledges have emerged through their specific experiences with neoliberal capitalist development, they nonetheless share a broad political interest. Drawing from Boaventura de Sousa Santos (2009, 2010), Martínez-Torres and Rosset (2014) argue that political struggles for food sovereignty and agroecology are based on 'absences' or subaltern knowledge 
systems that are marginalised by the monopoly of western, corporate and scientific knowledges. In struggles for social change, there are many equally valid ways of knowing the world and transformative learning provides a mechanism for these perspectives to come into dialogue, without one approach dominating another (Martínez-Torres and Rosset 2014). Bringing these together, social movements can produce important 'emergences' at different scales, which form the basis for solidarity, mutual understanding, collective learning and joint action.

In our European research, participants emphasized the importance of these dialogues across three dimensions: Amongst food producers with different positionnings and perspectives; Between food producers and other actors in the food system (especially food consumers); Between food producers and formal education and research institutions.

\section{Amongst Food Producers}

Because agroecology is based on a set of underlying ethics and principles which are flexible and not beholden to firm rules or certification, it lends itself to bringing farmers with diverse approaches and worldviews together in a diálogo de saberes. As Rupert Dunn, [a peasant farmer and baker from Wales], commented,

People often don't want to join the club [i.e. any one static and closed system of production] because they feel that they've got to change something about themselves in order to do it. What I like about agroecology is that we don't have to do that [...] I think it incorporates diversity

The agroecology learning initiatives thus brought together different traditions of sustainable agricultureincluding permaculture, biodynamics, and organic agriculture. In this way, agroecology functions as a 'boundary object' (i.e. information of different types used in different ways by different communities) which reflects commonly held values of autonomy, food sovereignty, localising food systems and collective knowledges (Anderson et al. 2014).

Many learning initiatives also stressed the importance of bringing together more experienced farmers with new entrants. In the Toekomstboeren program in the Netherlands, for example, an emphasis was put on bringing together an intergenerational network of agroecological producers, which often led to new opportunities for young people to enter farming both in terms of knowledge gained and gaining access to land and resources.

Because of the place-specificity of agroecology, participants argued that inter-place diálogo de saberes between people from different biophysical, cultural and political contexts can provide important opportunities for learning and innovation. For example, the importance of facilitating mobility within territories and between them (e.g. in inter-European and international exchanges) was repeatedly mentioned. As Dan Powell, [founder of the Landbase education project in England], stated:

You just can't learn everything at one place no matter how diverse it is. So to go to different places is really important...in the same way we were discussing about different countries just comparing between different farms. In the same region you could see people doing different things because of their skill based on their position and situation.

\section{Amongst food producers and other actors in the food system}

Although much emphasis has been put on farmer knowledge- exchanged especially through farmer-to-farmer learning-examples and debates in EAKEN also suggest that there is a need to emphasize a diálogo de saberes between farmers and other actors in the food system, especially consumers. For example, URGENCI, the international network for Community Supported Agriculture (CSA), emphasised the need to consider consumers as key subjects in agroecology and agroecology learning. In one example of their agroecological education work, Ugenci brought farmers and consumers together using theatre as a method to voice concerns, frustrations and dynamics of CSAs. Judith Hitchman, [President of URGENCI] described the potential of extending agroecology learning to work across the farmer-consumer divide, focusing particularly on political education, as a part of a process of building a wider social movement:

The 2 million people [producers and consumers] in URGENCI all have passive knowledge. The average producer feeds 40 families so you can work out from 2 million people how many producers that is. But the issue is that a great many people have non-political motivation - they find it's very fresh, very high quality it's organic, irrespective of whether it's certified or not. The issue is to bring the political knowledge to grassroots to both producers and consumers - as I said a moment ago they have passive knowledge... What concerns me is how to politicise the cross-cutting grassroots level...

For Judith, the participation of consumers in the political dynamics of agroecology was a rich but largely untapped potential for advancing food system transformation.

Another important diálogo de saberes in the network was between farmers and people whose knowledge is being applied in the development of appropriate farm technologies, farm inputs, and market outlets. For example, two of the 
learning initiatives represented in our initial work reflected a focus on community-developed appropriate technology for production and processing on small scale agroecological farms. Participants discussed how farmer autonomy in agroecology may in many cases be best acheived through interdependence with other actors who share a commitment to food sovereignty. Together they can co-produce innovations that reduce dependency on commercial inputs such as seeds, nutrients or farm machinery. The French cooperative, L'Atelier Paysan, and the UK-based Farm Hack focus on creating on-line and in-person open source learning and innovation communities between small-scale farmers, employees, engineers, software developers and agricultural development organisations. Based on this work, L'Atelier Paysan has begun to articulate and promote the concept of technology sovereignty for farm autonomy, which provides a political framework for the learning (L'Atelier Paysan 2016). This issue is discussed in greater detail in the section on connecting political and practical learning, below.

\section{Between farmers and mainstream research and education institutions}

Another important diálogo de saberes in agroecology learning can be seen amongst farmers and instructors in the formal education system. Many interviewees attributed some importance to the role of universities and formal education in agroecology, especially given the resources and reach of well-established education institutions. Yet, most had mixed experiences and perspectives reflecting the limiting nature of the institutional and cultural context of formal education in Europe. Participants described, for example, how mainstream institutions were unwilling or incapable of providing training that reflects and includes both the political rootedness and the practitioner-led learning considered essential by social movements.

While some recognised that there were courses on offer within some of these institutions that could be of technical use to agroecological farmer, these were considered generally disconnected from the political and social aspects of the agroecological movement, which rarely took a whole agri-food system approach. For example, Joel Holmdahl, [agroecology educator from Norway] suggested that "We have an increasing number of [...] university courses calling themselves agroecology actually lacking the social and political aspects of agriculture".

A few interviewees mentioned that agroecology courses in universities are primarily aimed at a graduate level, and are often targeted towards agroecological professionals, or experts, rather than farmers. Elske Hageraats [a peasant farmer from the Netherlands], discussing a course on agroecology at Wageningen University, expressed her frustration with the separation of the science of agroecology from the lived experiences of farmers and social movements.

During the agroecology course, the professors were only looking at the science and I asked: "where is the movement?" and they responded: "yeah well we don't really discuss that". I said: "you should also give students the chance to see first-hand, to visit farms and touch the soil". Someone then told me: "no, here in the university the students are trained to become researchers. If they want to become farmers, they can do that somewhere else"... It seems like most teachers don't see the point of all these connections, or maybe the university doesn't give them the opportunity to teach this. They just want a scientific output. They don't understand the importance of the other two aspects. Students hadn't heard about La Via Campesina, for example, which should definitely be part of it.

Where universities do engage with agroecology, however, interviewees were often critical of the minimal recognition given to farmer knowledge and of the perspectives of social movements, which tended to be viewed as mundane or biased. As Ana Gonzalez [a program coordinator from the Basque Country], from her organisation EHNE-Bizkaia, explained,

There is a tendency always to say social movements are so influenced by ideology that we normally accused them of being demagogic, but actually what we are trying to say that there is no knowledge in the world that is neutral or objective, and even the academy is based on certain values and principles that were decided by the elites who have decided that this is called academic knowledge.

Despite all these criticisms, however, some farmers' organisations in the network still consider that working with academic institutions can produce mutually beneficial outcomes. Ana went on to describe a healthy collaboration with the University of the Basque Country to develop a Masters program called "from the farm to the world." While it can be difficult to align the priorities and ways of knowing of universities and social movements, Ana viewed this as a process of negotiation leading to interesting outcomes based on a mutual commitment to self-transformation:

This is about how we are going to create a relationship. When we've finished an educational project [...] neither the social movements nor the universities are the same, we have influenced each other

As Ana argues, however, given the current role of higher education in the accumulation of power in a monopoly of elite knowledge, the potential for social movement 
engagement with formal institutions must especially involve a transformation of the university itself.

This is about making the university itself more peasant, more rural...we witnessed that most knowledge and theoretical approaches taught in universities are either directly influenced or lobbied by companies. The content they teach does not question at all the principles on which our economy is based or does not have anything to do with the problems of grassroot communities.

As Ana implies, simply bringing people into dialogue may not be enough, especially if how the dialogue unfolds results in no real questioning of the 'principles on which our economy is based'; some other mechanism or set of principles is needed to ensure one group doesn't simply dominate, and that 'on the ground' realities are adequately represented.

\section{Horizontal learning}

The second pillar of a Transformative Agroecology Learning approach is Horizontal Learning. or 'Horizontalism' is a central concept within popular education, and involves 'democratic communication on the same level and [... the intention to move towards] non-hierarchical and antiauthoritarian creation rather than reaction' (Sitrin 2006). In this sense, horizontalism can be contrasted to a 'banking' style of education where a teacher deposits expert knowledge into deficient students (Freire 1972). In accordance with this approach, many participants described their intention to recognise the ability of all people to think critically, act strategically, and contribute knowledge. As Jildou Friso [a small scale farmer from the Netherlands] summarised it, 'you shouldn't just be telling people things but leading by example'. Thus, transformative agroecology learning can be seen to position learners not as the object of teaching, but rather the subjects of their own process of learning, discovery and agency, as well as participants in the joint production of collective knowledge throughout their horizontal networks.

Three main aspects of horizontal learning which emerged as important for a transformative learning approach are: (i) strengthening learning experiences; (ii) building confidence and capacity; and (iii) challenging hierarchy through a prefigurative politics.

\section{Strengthening learning experiences}

Horizontal learning experiences were promoted by interviewees as producing more effective and durable learning outcomes than top-down knowledge transfer approaches to extension. These approaches often involve bringing the experiences of all learners into dialogue, avoiding singledirection forms of learning. Ashley Trill [a small scale farmer from the U.K.] described a similar dynamic in his experience of farmer-to-farmer learning at a Farm Hack event in the UK:

I've already learned basically more in the last two hours than I've learned in the last year of being alone weeding or whatever. Everyone here has something to say or a little gem of advice. Tiny little things that are so handy to know.

As with Ashley's sense that all participants had 'a little gem' to contribute, interviewees drew specific attention to the ways in which horizontal approaches fostered trust, genuine engagement and sharing between participants (often farmer-to-farmer) in learner-controlled processes. Ramona Duminicioiu [an activist and organizer from Romania], also stressed the efforts made by her organisation, Eco Ruralis, to take a non-hierarchical approach,

...to avoid making peasants feel like they are taught. They have been told for centuries that they are a burden that they are stupid, that they need to be told by the suits from the cities. We are trying to put peasants in situations where they are directing learning experiences.

Similarly, Rupert Dunn [a peasant farmer and baker from Wales] highlighted the importance of farmer-to-farmer dynamics, describing the, "moral support from someone who is a farmer saying, okay try these things out. I've been through that". In addition to the peership dynamics of horizontal learning environments, Rupert also remarked on the simple logic of these types of exchanges:

it's the only way to have appropriate and tangible accurate knowledges useful for farmers and farms. All farmers test a lot of techniques and systems on their farm and it's really important to be able to scale up all those initiatives and how to scale up is only by bringing people together to exchange it.

A horizontal approach recognises that farmers are more likely to believe and emulate a fellow farmer, than they are to learn production techniques from urban professionals. Due to its peer-to-peer format, the majority of our interviewees echoed Rupert's endorsement of a horizontal agroecology learning approach as a way to validate perspectives routinely sidelined in mainstream learning approaches.

\section{Building confidence and capacity}

Horizontal learning environments also have the advantage of fostering confidence in participants, emphasising that everyone has experience and knowledge to contribute in 
any learning environment (i.e. as teachers), as discussed by Jildou Friso [a small scale farmer from the Netherlands]:

Something that's really crucial to stimulate the process is to convince people what they know is relevant and that they hold the knowledge themselves.

Katalin Rethy [a program coordinator from Hungary] elaborated on this dynamic in her description of the importance of 'training the trainers'. Such a method, she explained, is essential for scaling up agroecology:

the trainers that we started to work with four years ago are now capable of training new ones, so it's really about generating local knowledge. We work in Budapest and some of the villages we work with are $150 \mathrm{~km}$ away so we are trying to do this knowledge transfer to have local people present in the communities who are employed through our projects to be able to have the knowledge themselves to spread.

Such confidence and capacity building, when embedded within a strategic program to scale up and scale out a learning program, can create a catalytic effect, where more learners become teachers and the process takes on a selfperpetuating momentum (Fakih et al. 2003; McCune and Sánchez 2019).

As Elske Hageraats [a small scale farmer from the Netherlands], pointed out that top-down training or 'big conferences' where 'everyone just presents and then just goes home' can come with a certain 'coldness'; by contrast, horizontal learning environments were consistently presented in terms of the personal connections and emotional processes they initiated, rather than only the instrumental and technical 'outputs':

the [agroecology] movement is about the feeling, not just the sharing. It is something more, something very deep and I think that has to be touched upon with cultural things like music, sharing, dreaming.

The deliberate fostering of a learning environment which set the grounds for mutual empowerment was a consistent priority amongst our interviewees, especially when bringing different knowledges together in a diálogo de saberes. In doing so, interviewees often put emphasis on relationality in the process, rather than learning geared only towards output or product. Across the board these were learning experiences centered on personal connections, not merely professional development. Ana Gonzalez [a program coordinator from the Basque Country], for example, described the importance of fostering an "ethos of mutual care" in intergenerational exchanges:

So it's also about learning from the technical side but also from the relationship side not to judge people.
To approach the older generation with more care and a humble attitude, in the way we should always pay attention to history from their side, and how we can set up a more sensitive dialogue with respect and feeling encouraged to teach the new entrants. And sometimes it's about stressing their role as educators. Because when you re-dignify the role, people feel better.

\section{Challenging hierarchy: a prefigurative politics}

Interviewees stressed how horizontal learning enacts democratic processes and relations that are consistent with the politics of food sovereignty itself. As one participant put it, food sovereignty is about, "the rights of communities to decide on the food systems they want to build up and participate in" [Ana Gonzalez, a program coordinator from the Basque Country]. As Ana explained, this was often based on a commitment to challenge hierarchy, wherever it is found:

[our approach] is all about how to make this knowledge more significant for social movements and... for the social struggles ... to challenge to the idea that academic knowledge is the only knowledge that can be considered objective or of any value.

More than a mere set of techniques, horizontalism reflects a commitment to prefigure the kind of bottom-up social change envisioned by the food sovereignty project (Sitrin 2006). In short, horizontal approaches are rooted in the belief in our collective ability to make history and transform society. As such, horizontal pedagogies seek to dissolve the mental blockages or prejudices that often translate into the disabling top-down practices of agricultural research and extension. Indeed, a key focus of horizontal learning approaches is breaking down deeply embedded mental stereotypes that cast farmers and rural people - and especially women - in subservient and helpless roles, even while their capacity to transcend such obstacles has been repeatedly demonstrated (see: Holt-Giménez 2006; Fakih et al. 2003; Machín Sosa 2013; Meek 2015; Rosset et al. 2011; Pimbert et al. 2017; People's Knowledge Editorial Collective 2017).

The political aspects of agroecology may to some seem somehow 'natural' or automatic, yet simply teaching agroecological practice will not automatically equate to political processes of social transformation. As we shall see in the following section the political and practical elements of training must be deliberately and carefully integrated. 


\section{Combining the practical and the political}

Connecting learning about the practical aspects of agroecological production with the political project of food sovereignty emerged as a third key priority for EAKEN members, particularly as something which was difficult to do or not already being done well. Ramona Duminicioiu [an activist and organizer from Romania], for example, pointed out that,

Agroecology training must also include the political...I come from a country where peasant farming is a way of life and it's still very vivid in the rural area. So training on how to do agriculture is not a necessary thing. This is happening naturally in the rural communities. But what is missing, and this is what is happening in agroecology, is a more political training on how to articulate our political demands and how to act on achieving political aims.

This emphasis on the political is reflective of attempts to culture political subjectivities through what Barbosa (2016) calls "educational-pedagogical praxis". Such practice emphasizes the central role of education in transforming peasants into historical-political actors as a precondition for political change. As Ana Gonzalez [a program coordinator from the Basque Country] explained, this arises from a pedagogical approach largely based on horizontalism, but also on the deliberate fostering of a lens in learners that critically views all practical problems as political rather than merely technical:

We want to promote our students to, starting from this critical spirit, become more active or participatory in any other spaces...how are you actually going to do that? By transforming people.

Through collective political dialogic learning, participants can form what Mansbridge and Morris (2001) call collective oppositional consciousness by critically analysing practical problems in the context of a common experience of subordination and to begin to self-identify as a part of a subordinated group. Linking localised learning activities to global discourses of food sovereignty and agroecology provides a basis for participants in social movements. As Julien Reynier [a cooperative organiser from France] from L'Atelier Paysan explained, collective political learning can help to overcome individualising tendencies and thus to promote collective subjectivities as the basis for collective action: 'the big issue is the individualism of many farmers today, even alternative farmers [...] they are not involved in farmer collective action'.

Importantly, the practical element of agroecology was for many a strategic way to draw people into political learning that could attract a wider range of participants who may otherwise not engage in such learning or collective action. Julien described this in the case of L'Atelier Paysan, an initiative that focuses on collective learning related to farm technology and tools:

Our strategy is that machinery is quite appealing to farmers and we don't have to struggle that much to bring people together around this topic...every farmer needs good machinery. And it's really important to increase the viability of your farm...That's why we think being more technical gives you the opportunity to get involved and at the same time we need people who can speak to the heart of the farmers and get them involved in political actions.

Similarly, EHNE-Bizkaia's agroecology training program in the Basque Country often leads with practical skills, moving on when participant confidence has increased to incorporate discussions on social movements and politics. This reflects a key aspect of critical pedagogic practice that starts with the knowledge and practical problems of the learner, but through dialogue and reflection locates this knowledge in the wider political and economic context. In the Romanian context, Ramona [an activist and organizer from Romania] described how the confidence and capacity for political analysis builds over time, increasing the critical consciousness of learners and their capacity to act on this new understanding.

We discovered that people who in the past were afraid to say anything regarding political issues are now curious and more interested and able to make connections between different discussions and agendas.

Learning on agroecological practice, in essence, can act as an on-ramp to engage with the politics of food sovereignty, which can then be translated into political action, as described by Peter Volz [a researcher from Germany],

...the second step is to enable action on a personal level, on a collective level but anyhow in the frame that these people are operating within.

While the belief in integrating the practical and the political was widely held amongst the people we spoke with, interviewees in many cases were less able to articulate precise approaches and methodologies for enabling this integration. Indeed, many of them pointed out that the simple act of gathering farmers together was a key strategy for political learning - "get farmers together and they will invariably turn to politics" [Diana Quiroz, a coordinator from the Netherlands].

While creating convivial space with time for free conversations on the occasions of practical training may lend itself to the emergence of political learning, there are also more explicit and systematic methods to enhance political 
learning. For instance, EAKEN has created an both face-toface and online spaces to cooperatively analyse and systematically share pedagogic examples, methods and resources to build capacity in combination of practical and political learning approaches.

\section{Building multi-scale social movement networks}

The final pillar of the Transformative Agroecological Learning approach focuses on building social movement networks. The horizontal scaling out of grassroots agroecological learning is largely driven by the processes identified thus far in this paper: critical education, diálogo de saberes, horizontal networks for peer-to-peer learning, and an emphasis on collective practical and political knowledge. All these processes depend on coordinated action made possible by local organizations that bring people together for joint activities-from resource management, labour-sharing, marketing, advocacy and other activities that would be too costly, or impossible, if done alone.

To this end, Guy Kastler [a peasant farmer from France], commented at one of the EAKEN meetings that, "there is no agroecology knowledge without strong farmer organisations", echoing the idea that agroecological knowledge is always collective (Nyéléni 2015). It is in organisations and networks that a knowledge commons is built and strengthened, and linked to the material and political project of food sovereignty.

All major success stories in grassroots agroecological education depend on nested local organizations to facilitate and coordinate collective action at different scales (Pimbert 2008, 2018). Decentralized and distributed local organizations play a key role in facilitating knowledge-sharing within transformative agroecological learning networks. Interlinked local organizations and collective structures provide the institutional landscape that enables the coordinated and timely exchange of agroecological knowledge within networks of food producers and consumers. This suggests that local organizations - and the networks they form-need to be strengthened in order to enhance the capacity to 'scale out' the transformative agroecological learning processes described here.

In many cases, participants in the network spoke of education as an intentional strategy to strengthen local organisations, contributing to what has been called a territorialisation of agroecology (McCune and Sánchez 2019; Wezel et al. 2016). As Julien Reynier [a cooperative organiser from France] from L'Atelier Paysan put it, "the method is trying to build communities".

Agroecology training was also viewed as important in building national political networks, where, for example, learning initiatives like Land Base and Farm Hack in the UK were linked to, and help to enrol new participants into the Land Workers Alliance (a UK member of La Via Campesina). Ramona [an activist and organizer from Romania] described how their combination of practical and political learning helps to expand enrolment in the Romanian member organisation Eco Ruralis:

Political issues are always part of these meetings in a transversal way... what is happening with legislation around seeds or GMOs, what can we do in Romania, if we need to go on alert or call our MEPs .... and slowly, in a transversal way, it builds a flow of information, and it builds slowly a base.

Network building through transformative agroecology learning was multi-scaled in nature: EAKEN, which aims to support local, regional and national initiatives is connected to a global strategy by La Via Campesina to develop capacity in agroecology learning approaches, methodologies and experiences. By building international networks, new possibilities arise for exchange and the international mobility of pedagogical innovations from one location to another through a dialogos de saberes. For example, learning from Latin American social movements was important for EHNEBizkaia which now has one of the most extensive agroecology education programs among all the initiatives currently in EAKEN. Ana Gonzalez [a program coordinator from the Basque Country] explained,

The main strategy for EHNE-Bizkaia, and our experience with La Via Campesina has allowed us to learn from others how to do things or how to set up educational trainings which were creating a different perspective, we have received much more influence from Cuba on how to set up educational programs from the perspective of agroecology

These multi-scaled networks are critical for the sharing of agroecological knowledges and pedagogies across places, building capacity for further learning. As Mamen Cuéllar Padilla [an activist-research from Spain] described, these networks provide an opportunity to support innovation in pedagogic approaches, especially in terms of the transformative aspects of agroecology learning:

We can exchange proposals, thinking, methodologies, contents, materials, documents, experiences and practice but also it could help to strengthen this vision of knowledge dialogue, horizontal power relations, the role of academia in this knowledge creation and this training action.

Learning programs linking farmers to organisations that are advancing food sovereignty was also viewed as a key element of developing a sense of collective consciousness. Participation in these organisations affirms the identity and the work of peasants and agroecologists, strengthens 
commitment to advancing agroecology and provides a sense of belonging to a wider social movement. As Jildou Friso [a peasant farmer from the Netherlands] described,

...it's such a struggle to go on with agroecology practice. Just the feeling of being a part of a network is very empowering. If you share your knowledge and people from other countries are interested in what you're doing it can be very empowering - it's a small but important point.

Most of the initiatives in this study were connected to La Via Campesina who are articulating strong positions and campaigns for food sovereignty. Agroecological learning can connect learners into these multi-scaled networks and organisations which act as mobilising structures for political work at local, national and international levels. These organisations provide critical mechanisms for exercising dissent and countervailing power, which is a mainstay of social movement practice (Freire 1972). However, these networks were also charachterised by uneven participation in these learning and knowledge exchange opportunities. As Judith Hitchman [President of URGENCI] suggested,

Even with all the European projects we're doing, to a large extent it's the top $10 \%$ of the leadership. What concerns me is how to politicise and get the knowledge and training down to the cross-cutting grassroots level.

While we will address this in greater detail in the following section, many interviewees saw the combining of practical and political learning as a way to address such unevenness; that is, as a means to sustain the link between abstract political work and particularised agroecological practice. Ramona [an activist and organizer from Romania] elaborated,

We need to keep both connected because people that are getting involved in political actions tend to lose the connections with people that are involved in practical activities.

\section{Discussion}

The initiatives and approaches we characterised in this paper as a part of EAKEN are explicitly developing agroecology learning as a method of social transformation. In this context, learning was couched for the specific purpose of enabling transformation and was a strategy for social movement mobilisation. In addition to technical learning, these citizen-led initiatives base their work on four additional pillars: Horizontalism; Diálogo de saberes; Combining practical and political; and building social movement networks (Fig. 2).

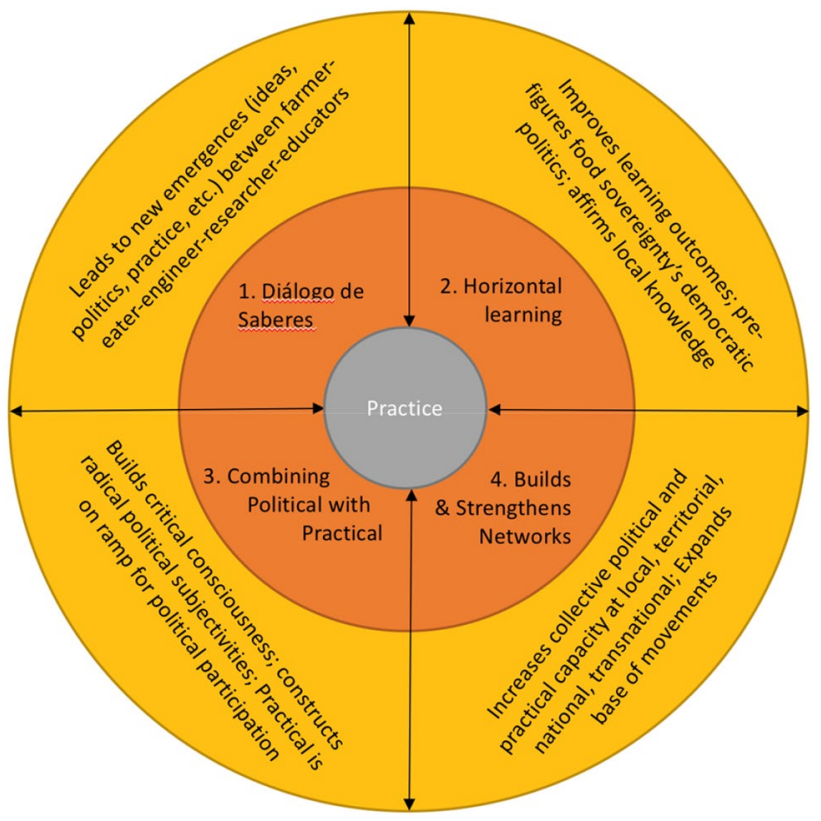

Fig. 2 Transformative agroecology framework involves a pedagogical approach that always has practice as a central component, but also relies on four pillars (orange segments) to provide the "connective tissue' to the political project of food sovereignty (yellow circle). (Color figure online)

While we have presented the four pillars of agroecology learning as distinct, our findings also provide insight into the interdependencies and tensions that arise within and between them. Indeed, these dynamics are a crucial part of advancing current thinking on transformative agroecology learning. For example, the expanded vision of a multi-actor diálogo de saberes is a frontier for the agroecology movement in Europe. That is, opening up opportunities for learning between farmers and other constituents such as citizenfood-consumers, researchers and educators comes with risks, as the positionality of different actors implies intersecting and uneven relations of power. Indeed, our results reiterated how farmer knowledge is often structurally and culturally subordinated by urban and professional knowledges and interests. Thus, these dialogues (pillar 1) must be developed with caution and critical reflexivity. To this end it is essential to establish mutually agreed upon protocols and pedagogies based on horizontalism (pillar 2) to preempt the emergence of exploitative hierarchies. For example, in the early development of EAKEN, there have been careful steps taken to ensure that farmers have safe spaces to articulate their own priorities and needs, to focus on dialogue amongst different food producers, and to strategically engage in these wider dialogues as the opportunities to do so are developed.

Yet, the challenge remains that while there is a recognition of the need for these wider cross-constituent dialogues and partnerships, action too easily falls back into old silos 
(Anderson et al. 2017a, b). Indeed, our framework encourages work that is embedded in social movement organisations (pillar 4) which are often based on single constituencies (e.g. peasants). This suggests that the ability to foster cross-constituency dialogues may require network and organisational innovations to create new spaces for this dialogue to occur, based on horizontal relations. This is fundamentally important to building solidarity and conditions for allyship between differently positioned actors in the food sovereignty movement.

One emergent, yet tension-ridden diálogo de saberes was between food producers and other actors of the food system which reflects the increasing, but unmet, call to move from a farm-level focus to a whole food system approach to agroecology (Wezel et al. 2009, 2016). This systems approach recognizes that transforming the food system will be impossible without the practical and political participation of non-producers (González de Molina 2013) (i.e. consumers). In contrast to research on diálogo de saberes in the global south where the focus was on rural-constituents (Martínez-Torres and Rosset 2014), this wider dialogue may be especially salient in a highly urbanised Europe where significant challenges remain in making food sovereignty relevant to the lives of urban non-producing people. Based on a weaving of practical and political learning between farmers, food workers and consumers, a transformative agroecology learning may address some of the critiques of alternative food networks (which link producers and consumers) and their tendency to depoliticise consumers (e.g. Johnston et al. 2009). Conceptualising these interactions as potential moments of critical and political learning remains an important opportunity to mobilize people who buy food from agroecology farmers as more-than-consumers, but also as "historical-political actors" (Barbosa 2016) in struggles for food sovereignty.

An example of a positive synergy between the pillars, is the ability of a horizontal approach (pillar 2) to build capacity and confidence amongst learners, who can become active participants, organisers and leaders in social movement organisations (pillar 4). A top-down approach to learning can foster passivity and reinforce hierarchies between expert teacher-leaders and lay learner-followers, thus undermining the potential to expand participation in developing social movement organisations. By providing opportunities for learners to begin to provide active input and leadership in organizations (rather than only provide instrumental input or token involvement) through applying their political learning in organising campaigns or becoming facilitator-teachers in learning initiatives, these networks can be expanded and strengthened, as demonstrated in the case of the Cuban ANAP and Brazilian MST movements (McCune and Sánchez 2019; Rosset et al. 2011).
Across the network, there were clear differences amongst the organisations in terms of whether transformative agroecology learning was used as an explicit organisational strategy. For some, agroecology learning was a core and integrated element of organisational strategies. For others, it was minor and disconnected from other activities, such as advocacy. If transformative agroecology learning is genuinely to provide the 'connective tissue' between food sovereignty and agroecology, there is a need to: (a) strategically plan to incorporate it as a part of an integrated organisational development strategy; (b) contribute resources to the systematisation and improvement of transformative agroecological learning praxis. In regards to the latter, the four pillars were unevenly developed across EAKEN member organisations, and in many cases the precise methods and approaches to implementing the four pillars were difficult for many of the interviewees to articulate.

While a number of understandable factors (such as funding constraints, recent establishment, and minimal integration into international networks) contributed to this unevenness, there is a danger that, without systematisation and critical reflection, such organisations might easily fall back into dominant modes of learning (e.g. technical, top-down) and de-prioritize bottom-up transformative learning as an indispensable mode of social movement building. Compared to more conventional agroecology learning, these pillars require the continual systematic reappraisal, redesign and reinvention in response to the evolving dynamics of the organisation (e.g. as participant composition evolves) and changes in the wider context (e.g. as the food crisis develops).

The systematisation of transformative agroecological learning approaches is one of the key purposes of EAKEN, as well as the global articulation coordinated by La Via Campesina. These connections, between the European and Global network can provide opportunities for organisation-to-organisation learning, especially from regions and organisations that have advanced further. For example, in the MST, an education sector and the [political] formation sector create organisational structures to intentionally develop the linkages between education and movement building (McCune and Sánchez 2019). Networks like EAKEN, we argue, are key to facilitating inter-organisational learning and helping to more systematically incorporate transformative learning into social movement strategies.

While agroecology learning is relatively embryonic across Europe, its potential as a tool to build up social movement networks has been exemplified in the Cuban Campesino-to-Campesino movement, where, through social processes of learning, the program built up a base made up of $50 \%$ of all the peasant families in $\mathrm{Cuba}^{1}$ (Rosset et al. 2011).

\footnotetext{
1 A multimedia resource for learning about the Cuban experience can be found here: http://agroecologia.espora.org/.
} 
Of course, there are many differences between the European context and the Cuban or other Latin American countries where much of the literature on agroecology learning has been developed. First, there is generally a larger peasant contingent in the Latin American context, with denser networks. Next, there is a much stronger tradition of popular education, whereas in Europe these traditions have been weakened through the neoliberal period. Finally, whereas in many Latin American contexts, peasant social movements have long advanced agroecology within an anti-capitalist and decolonizing framework, peasant movements in Europe have only recently began to embrace a transformative agroecology for food sovereignty (Nyéléni 2017; Pimbert 2015). There are also a wide range of powerful governmental, scientists and non-governmental institutions that are competing to define a European articulation of agroecology-including competing notions of the practices and politics of learning and training. In this context, the meaning and the doing of agroecology is far more ambiguous and up for grabs, making the transformative agroecology learning more urgent, yet also more challenging.

\section{Conclusion}

Our analysis contributes to the theory of learning for transformative agroecology based on four key processes: horizontalism; diálogo de saberes (wisdom dialogues); combining practical and political knowledge; building social movement networks. While theories of transformative learning often focus on individual learning processes, our approach was to conceptualise learning as an integral part of the process of social movement building. This resonates strongly with other contributions in this special issue where learning focuses on territorial integration (McCune and Sánchez 2019) or a process of local dynamization (López-García et al. 2019). In this context, the four key processes described here could provide a tool to for social movements to strategically and reflexively systematize and strengthen a transformative learning approach. While this was applicable in the context of agroecology for food sovereignty, this framework may also be relevant for other movements.

The research rasises further questions about the nature of transformative learning. For example, in terms of the systematisation of current practice, what are the organisational, methodological and institutional innovations that can support bottom up learning and critical education in a durable way? How can state funding shift from the current emphasis on top-down technological fixes, towards appropriately supporting the decentralised social learning processes being advanced by social movements? Similarly, how can farmers and other actors meaningfully participate in transformative agroecological learning on a long-term basis given the precarity of their own material circumstances (Calvário 2017; Pimbert 2011). Although we have focused on collective learning processes as a social movement strategy, further work is needed to understand how this social-political pedagogy is connected to individual transformative learning processes (e.g. Mezirow 1997).

Next, the actual processes and methods for enabling diálogo de saberes and horizontalism in agroecology learning requires further close scrutiny, especially the role of educators and facilitators, to better understand what attitudes, behaviors and skills are required for a transformative learning approach. More work is needed to understand how learning approaches should be, like agroecology practices themselves, adapted to contingencies of place including the biophysical, organisational, historical, cultural and institutional differences between places. While it is recognised that the potential of a transformative agroecology learning will only be realised to the extent that it contributes to territorial processes of agroecological dynamisation (McCune and Sánchez 2019; López-García et al. 2019), there is little known about how to adapt to differential territorial contexts. Finally, many questions remain to better understand the specific processes within each of the domains and further in-depth research is needed to examine, for example, how to most effectively engage a wide diversity of actorsoften with uneven relations of power-in learning for transformation.

The systematisation of a transformative agroecology learning is a critical step for regions, movements and groups seeking to advance the project of food sovereignty. This article offers a contribution to this process of systematisation and highlights a range of evolving processes from the European context. Through collective learning that links agroecology practices with the political project of food sovereignty, social movements are advancing a broader transformation towards a more just and sustainable food system.

Open Access This article is distributed under the terms of the Creative Commons Attribution 4.0 International License (http://creativeco mmons.org/licenses/by/4.0/), which permits unrestricted use, distribution, and reproduction in any medium, provided you give appropriate credit to the original author(s) and the source, provide a link to the Creative Commons license, and indicate if changes were made.

\section{References}

Adams, F., and M. Horton. 1975. Unearthing seeds of fire: the idea of Highlander. Winston Salem: John F. Blair.

Aerni, P. 2011. Food sovereignty and its discontents. ATDF Journal $8(1-2): 23-40$.

AgriCultures Network. 2013. Brazil launches agroecology plan. AgricCultures Network. http://www.agriculturesnetwork.org/news/brazi 1-agroecology-plan. Accessed 27 July 2016. 
Alonso-Fradejas, A., S. M. Borras Jr, T. Holmes, E. Holt-Giménez, and M. J. Robbins. 2015. Food sovereignty: convergence and contradictions, conditions and challenges. Third World Quarterly 36 (3): 431-448.

Altieri, M. 2009. Agroecology, small farms, and food sovereignty. Monthly Review 61: 102-113

Altieri, M. A., and V. M. Toledo. 2011. The agroecological revolution in Latin America: rescuing nature, ensuring food sovereignty and empowering peasants. Journal of Peasant Studies 38 (3): 587-612.

Amsler, S. S. 2015. The education of radical democracy. New York: Routledge.

Anderson, C. R., W. McDonald, J. Gardiner, and S. McLachlan. 2014. Navigating the fault lines in civic food networks. Journal of Agriculture, Food Systems and Community Development, 4 (3): 79-99.

Anderson, C. R., Silivay J. and K. Lobe. 2017a. Community organisations for food systems change: reflecting on food movement dynamics in Manitoba. In Everyday experts: how people's knowledge can transform the food system, ed. Peoples Knowledge Collective. Coventry: Coventry University.

Anderson, C., C. Maughan, and M. Vizy. 2017b. Developing a European agroecology learning and training network: research brief. Centre for Agroecology, Water and Resilience and the European Coordination of Via Campesina. https://www.eurovia.org/eaken I. Accessed 18 September 2018.

Barbosa, L. P. 2016. Educação do Campo [education for and by the countryside] as a political project in the context of the struggle for land in Brazil. The Journal of Peasant Studies 44 (1): 118-143.

Bernstein, H. 2014. Food sovereignty via the "peasant way": a sceptical view. Journal of Peasant Studies 41 (6): 1031-1063.

Broadbridge, E., U. Jonas, and C. Warren. 2011. The school for life: NFS Grundtvig on education for the people, vol. 1. Aarhus: Aarhus Universitetsforlag.

Calvário, R. 2017. Food sovereignty and new peasantries: on re-peasantization and counter-hegemonic contestations in the Basque territory. The Journal of Peasant Studies 44 (2): 402-420.

Coolsaet, B. 2016. Towards an agroecology of knowledges: recognition, cognitive justice and farmers' autonomy in France. Journal of Rural Studies 47 (A): 165-171.

De Sousa Santos, B. 2009. Una epistemología del sur: la reinvención del conocimiento y la emancipación social. Siglo XXI.

De Sousa Santos, B. 2010. Descolonizar el saber, reinventar el poder. Ediciones Trilce.

Desmarais, A. A. 2007. La Vía Campesina: globalization and the power of peasants. Halifax: Fernwood.

Dewey, J. 1916. Education and democracy: an introduction to the philosophy of education.

ECVC. European Coordination of Via Campesina. n.d. European Agroecology Knowledge Exchange Network. https://www.eurovia.org/ eaken/. Accessed 18 September 2018.

ECVC. 2017. Monkton wyld statement on agrecology knowledge exchange. ECVC. Retrieved from http://www.eurovia.org/wpcontent/uploads/2017/02/2017-02-Monkton-Wylde-Statementon-Agroecology-Knowledge-Exchange.pdf.

Edelman, M. 2014. Food sovereignty: forgotten genealogies and future regulatory challenges. The Journal of Peasant Studies 41 (6): 959-978.

Fakih, M., T. Rahardjo, and M. P. Pimbert. 2003. Community integrated pest management in Indonesia: Institutionalising participation and people centered approaches. London: International Institute for Environment and Development (IIED), Institute for Development Studies (IDS), and REaD.

FAO. 2018. Catalysing dialogue and cooperation to scale up agroecology: Outcomes of the FAO Regional Seminars on Agroecology.
Rome: FAO. http://www.fao.org/3/I9035EN/i9035en.pdf. Accessed 19 September 2018.

Ferrer, A. T. 1996. The workers' movement and popular education in contemporary Spain (1868-1939). Paedagogica Historica 32 (3): 647-684.

Francis, C., T. A. Breland, E. Østergaard, G. Lieblein, and S. Morse. 2013. Phenomenon-based learning in agroecology: a prerequisite for transdisciplinarity and responsible action. Journal of Sustainable Agriculture 37 (1): 60-75.

Freire, P. 1972. Pedagogy of the oppressed. New York: Herder.

Giraldo, O. F., and P. M. Rosset. 2018. Agroecology as a territory in dispute: between institutionality and social movements. The Journal of Peasant Studies 45 (3): 545-564.

Gliessman, S. R. 2014. Agroecology: the ecology of sustainable food systems. Boca Raton: CRC Press.

González de Molina, M. 2013. Agroecology and politics. How to get sustainability? About the necessity for a political agroecology. Agroecology and Sustainable Food Systems 37 (1): 45-59.

Gramsci, A. 1971. Selections from the Prison Notebooks of Antonio Gramsci. Edited and Translated by Quintin Hoare and Geoffrey Nowell Smith. International Publishers.

Guthman, J. 2018. Agrarian dreams: the paradox of organic farming in California. 2nd ed. Oakland: University of California Press.

Holt-Giménez, E. 2006. Campesino a campesino: voices from Latin America's farmer to farmer movement for sustainable agriculture. Oakland: Food First.

Holt-Giménez, E., and M. Altieri. 2016. Agroecology "lite:" cooptation and resistance in the global north. Food First. https://foodf irst.org/agroecology-lite-cooptation-and-resistance-in-the-globa 1-north/. Accessed 19 September 2018.

IAASTD (International Assessment of Agricultural Knowledge, Science and Technology for Development). 2009. Synthesis report: a synthesis of the global and sub-global IAASTD reports. Washington: IAASTD.

Johnston, J., A. Biro, and N. MacKendrick. 2009. Lost in the supermarket: The corporate-organic foodscape and the struggle for food democracy. Antipode 41 (3): 509-532.

L'Atelier Paysan. 2016. Plaidoyer: souveraineté technologique des paysans. http://www.latelierpaysan.org/Plaidoyer-souverainete-techn ologique-des-paysans. Accessed 19 July 2017.

La Via Campesina (LVC). 2013. From Maputo to Jakarta: 5 years of agroecology in La Vía Campesina. Jakarta. http://viacampesi na.org/downloads/pdf/en/de-maputo-a-yakarta-en-web.pdf. Accessed 1 January 2018.

Lang, T. 2010. Crisis? What crisis? the normality of the current food crisis. Journal of Agrarian Change 10 (1): 87-97.

Lélé, S. M. 1991. Sustainable development: a critical review. World Development 19 (6): 607-621.

Levidow, L. 2015. European transitions towards a corporate-environmental food regime: agroecological incorporation or contestation? Journal of Rural Studies 40: 76-89.

Levidow, L., M. P. Pimbert, and G. Vanloqueren. 2014. Agroecological research: conforming - or transforming the dominant agrofood regime? Agroecology and Sustainable Food Systems 38 (10): $1127-1155$.

López-García, D., L. Calvet-Mir, M. Di Masso, and J. Espluga. 2019. Multi-actor networks and innovation niches: university training for local agroecological dynamization. Agriculture and Human Values. https://doi.org/10.1007/s10460-018-9863-7.

Machín Sosa, B. 2013. Agroecological revolution: the farmer-to-farmer movement of the ANAP in Cuba [online]. Havana and Jakarta: ANAP and La Vía Campesina.

Mansbridge, J. J., and A. Morris. 2001. Oppositional consciousness: the subjective roots of social protest. Chigago: University of Chicago Press. 
Martínez-Torres, M. E., and P. M. Rosset. 2014. Diálogo de saberesin La Vía Campesina: food sovereignty and agroecology. The Journal of Peasant Studies 41: 979-997.

McCune, N., and M. Sánchez. 2019. Teaching the territory: agroecological pedagogy and popular movements. Agriculture and Human Values. https://doi.org/10.1007/s10460-018-9853-9.

McMichael, P. 2008. Peasants make their own history, but not just as they please. Journal of Agrarian Change 8 (2-3): 205-228.

Meek, D. 2015. Learning as territoriality: the political ecology of education in the Brazilian landless workers' movement. The Journal of Peasant Studies 42 (6): 1179-1200.

Meek, D., and R. Tarlau. 2016. Critical food systems education (CFSE): educating for food sovereignty. Agroecology and Sustainable Food Systems 40 (3): 237-260.

Méndez, V. E., C. M. Bacon, R. Cohen, and S. R. Gliessman. 2015. Agroecology: transdisciplinary, participatory and action-oriented approach. Boca Raton: CRC Press.

Mezirow, J. 1997. Transformative learning: theory to practice. New Directions for Adult and Continuing Education 74: 5-12.

Mier y Terán Giménez Cacho, M., O. F. Giraldo, M. Aldasoro, H. Morales, B. G. Ferguson, P. Rosset, A. Khadse, and C. Campos. 2018. Bringing agroecology to scale: key drivers and emblematic cases. Agroecology and Sustainable Food Systems 42 (6): 637-665.

MST. 2005. Dossiê MST - Escola. Documentos e estudos 1990-2001. In Caderno de Educação, n ${ }^{\circ}$ 13. 2a Edição. São Paulo: Expressão Popular.

Nyéléni. 2007. Nyéléni 2007—forum for food sovereignty—full report. Nyéléni-forum for food sovereignty. http://Nyeleni.org/DOWNL OADS/Nyelni_EN.pdf. Accessed 18 September 2018.

Nyéléni. 2015. Nyéléni 2015-Declaration of the international forum for agroecology. Nyéléni-forum for food sovereignty. http:// www.foodsovereignty.org/forum-agroecology-Nyeleni-2015/. Accessed 18 September 2018.

Nyéléni Europe. 2017. Nyéléni pan-European forum for food sovereigty, Cluj Napoca-Romania-Expo Transilvania, 25-30 October 2016. Cluj Napoca-Romania: Nyéléni Europe. http://Nyele nieurope.net/sites/default/files/2017-04/Nyeleni\%20Europe\%20 Report\%202016_web.pdf. Accessed 18 September 2018.

Patel, R. 2009. Food sovereignty. The Journal of Peasant Studies 36 (3): 663-706.

Pelloutier, F. 1901. Histoire des bourses du travail. London: Routledge.

People's Knowledge Editorial Collective (Eds). 2017. Everyday experts: how people's knowledge can transform the food system. Coventry: Coventry University.

Pimbert, M. P. 2008. Towards food sovereignty: reclaiming autonomous food systems. London: International Institute for Environment and Development (IIED).

Pimbert, M. P. 2011. Participatory research and on-farm management of agricultural biodiversity in Europe. London: International Institute for Environment and Development (IIED).

Pimbert, M. P. 2015. Agroecology as an alternative vision to conventional development and climate-smart agriculture. Development 58 (2-3): 286-298.

Pimbert, M. P., P. V. Satheesh, A. Argumedo, and T. M. Farvar. 2017a. Participatory action research transforming local food systems in India, Iran and Peru. In: People's Knowledge Editorial Collective (Eds). Everyday Experts: How people's knowledge can transform the food system. Reclaiming Diversity and Citizenship Series. Coventry: Coventry University. http://www.coventry.ac.uk/every day-experts.

Pimbert, M. P. 2018. Food sovereignty, agroecology and biocultural diversity. Constructing and contesting knowledge. London: Routledge.
Rosset, P. M., and M. A. Altieri. 2017. Agroecology, science and politics. Winnipeg: Fernwood.

Rosset, P. M., B. Machín Sosa, A. M. Roque Jaime, and D. R. Ávila Lozano. 2011. The Campesino-to-Campesino agroecology movement of ANAP in Cuba: social process methodology in the construction of sustainable peasant agriculture and food sovereignty. Journal of Peasant Studies 38 (1): 161-191.

Sitrin, M. 2006. Horizontalism: voices of popular power in Argentina. Oakland, CA: AK Press.

Tittonell, P., L. Klerkx, F. Baudron, G. F. Félix, A. Ruggia, D. van Apeldoorn, S. Dogliotti, P. Mapfumo, and W. A. Rossing. 2016. Ecological intensification: local innovation to address global challenges. In Sustainable Agriculture Reviews (pp. 1-34). Springer.

Warner, K. 2007. Agroecology in action: extending alternative agriculture through social networks. Cambridge, Mass: MIT.

Wezel, A., S. Bellon, T. Doré, C. Francis, D. Vallod, and C. David. 2009. Agroecology as a science, a movement and a practice. A review. Agronomy for Sustainable Development 29 (4): 503-515.

Wezel, A., H. Brives, M. Casagrande, C. Clément, A. Dufour, and P. Vandenbroucke. 2016. Agroecology territories: places for sustainable agricultural and food systems and biodiversity conservation. Agroecology and Sustainable Food Systems 40 (2): 132-144.

Wittman, H. 2011. Food sovereignty: a new rights framework for food and nature? Environment and Society 9 (1): 87-105.

Colin R. Anderson is a Senior Research Fellow at the Centre for Agroecology, Water and Resilience, Coventry University. His research focuses on community- and people- led processes of transformation for resilience, social justice and well-being. He works with communities, networks and organizations who are adressing the multitude of social, economic and cultural problems we face today and who are reimaging society and building alternatives. His collaborative research contributes to the development of thinking and action related to food systems, community building, food sovereignty, activism, and knowledge mobilization, and especially focuses on the workings of power, resilience, and regeneration in these areas. Visit https://www.agroecologynow.com and https://www.peoplesknowledge.org to learn more.

Chris Maughan is a British Academy Postdoctoral Fellow based at the Centre for Agroecology, Water and Resilience. His research interests include the role of popular education, grassroots innovation processes, and inclusive governance in the development and realisation of agroecological food systems. He is currently leading on a research project designed to develop the latest theory on innovation processes and draw from bottom-up knowledge exchange processes and community economies theory to propose new ways to scale-up agroecological innovation. This project draws together the analysis of bottom-up processes of horizontal knowledge exchange and interactive innovation in agroecology networks, in order to develop a more holistic theory of innovation that can better harness the economic, social, cultural and political processes needed to develop a just and sustainable food system.

Michel P. Pimbert is Professor of Agroecology and Food Politics at Coventry University and the Director of the Centre for Agroecology, Water and Resilience in the UK. His research interests include agroecology and food sovereignty; the political ecology of biodiversity and natural resource management; participatory action research methodologies; and deliberative democratic processes. He works with networks of small and family farmers, indigenous peoples, and communities to advance transdisciplinary ways of knowing that regenerate local ecologies, economies and cultural diversity. 